\title{
PENGARUH PEMBERIAAN SEDIAAN EMULGEL CHITOSAN- EKSTRAK BIJI PINANG (ARECA CATECHU .L) DAN EMULGEL CHITOSAN-EKSTRAK DAUN KEDONDONG (SPONDIAS DULCIS FROST) TERHADAP PENYEMBUHAN LUKA BAKAR PADA TIKUS
}

\author{
Poppy Dwi Citra Jaluri ${ }^{1}$ Merry Hardiani $^{2}$ Nur Anidah ${ }^{3}$ \\ ${ }^{123}$ STIKes Borneo Cendekia Medika Pangkalan Bun \\ ${ }^{1}$ email : poppyjaluri@gmail.com, ${ }^{2}$ email : merryhardiani18@gmail.com, \\ 3email : anidahnur53@gmail.com
}

\begin{abstract}
ABSTRAK
Pendahuluan: Luka bakar adalah suatu bentuk kerusakan atau kehilangan jaringan yang disebabkan kontak dengan sumber panas, bahan kimia, listrik dan radiasi. Biji pinang (Areca catechu.L) dan daun kedondong (Spondias dulcis Frost) memiliki khasiat sebagai obat tradisional yang dapat mempercepat proses penyembuhan luka bakar. Penelitian ini bertujuan untuk mendapatkan formulasi sediaan emulgel chitosan-ekstrak biji pinang (Areca catechu.L) dan formulasi sediaan emulgel chitosan-ekstrak daun kedondong (Spondias dulcis Frost) terhadap penyembuhan luka bakar pada tikus.Metode Penelitian: Penelitian yang dilakukan adalah jenis penelitian true experimental laboratories dengan rancangan penelitian pre-post test only control group. Menggunakan hewan uji tikus putih sebanyak 24 ekor. Setiap group terdiri dari 4 kelompok perlakuan yaitu kontrol positif, kontrol negatif, emulgel konsentrasi $10 \%$ dan $20 \%$. Luka bakar dibuat menggunakan besi panas. Selama \pm 10 detik pada bagian punggung tikus. Data yang diperoleh dianalisi menggunakan uji one-way ANOVA dengan taraf kepercayaan 95\% untuk mengetahui adanya perbedaan yang sifnifikan antar kelompok perlakuan.Hasil dan Pembahasan: Hasil uji post hoc emulgel-kitosan biji pinang diperoleh konsentrasi efektif dengan nilai signifikn 0,000 dibandingkan dengan kontrol negatif serta diperoleh konsentrasi paling efektif yaitu emulgel 20\%. Hal ini terbukti berpengaruh efektif terhadap penurunan luka bakar. Konsentrasi yang paling efektif adalah emulgel dengan konsentrasi 20\%. Hasil analisis pada hari ke-21 menunjukkan emulgel ekstrak daun kedondong konsentrasi $20 \%$ memiliki efektivitas penyembuhan luka yang tidak berbeda signifikan dengan konsentrasi $10 \%$. Emulgel ekstrak daun kedondong konsentrasi $20 \%$ memiliki potensi penyembuhan luka bakar yang lebih baik.
\end{abstract}

Kata kunci: Emulgel, Biji pinang (Areca catechu .L), Daun Kedondong (Spondias dulcis Frost), Kitosan, Luka bakar, Penyembuhan luka.

THE EFFECT OF PROVISION OF CHITOSAN EMULGEL-EXTRACT 


\title{
OF ARECA NUT (ARECA CATECHU. L) AND CHITOSAN \\ EMULGELS - EMBROIDED LEAF EXTRACT (SPONDIAS \\ DULCIS FROST) ON HEALING OF FUEL PAIN WOMEN AND \\ CHITOSAN EMULGELS - EXTRACT OF KEDONDONG LEAVES (SPONDIAS DULCIS FROST)
}

\begin{abstract}
Burns are a form of tissue damage or loss caused by contact with sources of heat, chemicals, electricity and radiation. Areca nut (Areca catechu. L) and kedondong leaves (Spondias dulcis Frost) have properties as traditional medicine that can accelerate the healing process of burns. The aim of this study was to obtain a formulation of chitosan emulgel-areca nut extract (Areca catechu. L) and chondosan-emulgel formulation of kedondong leaf extract (Spondias dulcis Frost) on the healing of burns in rats. The study was a true experimental laboratories research with a pre-post test only control group research design. Using 24 white rat test animals. Each group consisted of 4 treatment groups namely positive control, negative control, $10 \%$ emulgel concentration and 20\%. Burns made using hot iron. For \pm 10 seconds on the back of the rat. The data obtained were analyzed using a one-way ANOVA test with a confidence level of $95 \%$ to find significant differences between treatment groups. The results of post hoc emulgel-chitosan betel nut seeds obtained effective concentrations with a significant value of 0,000 compared with negative controls and obtained the most effective concentration of $20 \%$ emulgel. This has proven to be an effective effect on reducing burns. The most effective concentration is emulgel with a concentration of $20 \%$. The results of the analysis on the 21 st day showed emulgel kedondong leaf extract concentration of $20 \%$ had the effectiveness of wound healing which was not significantly different from the concentration of 10\%. Emulgel kedondong leaf extract concentration of $20 \%$ has the potential for better healing of burns.
\end{abstract}

Keywords: Emulgel, Areca nut (Areca catechu. L), Kedondong Leaf (Spondias dulcis Frost)., Chitosan, Burns, Wound healing.

\section{PENDAHULUAN}

Luka bakar merupakan salah satu trauma yang sering terjadi dalam kehidupan sehari-hari, bahkan sering kali merupakan kecelakaan massal. $70 \%$ kejadian luka bakar terjadi di lingkungan rumah tangga, 25\% di tempat industri dan kira-kira 5\% akibat kecelakaan lalu lintas. Kebanyakan luka bakar terjadi di rumah ketika memasak atau penggunaan alat elektronik tidak sesuai, anak-anak dan lanjut usia memiliki resiko tinggi terhadap cedera luka bakar. Kedua kelompok ini memiliki kulit tipis dan rapuh, sehingga kontak dalam waktu yang 
sebentar dengan sumber panas dapat mengakibatkan luka bakar ketebalan penuh (Kristanto H, 2005, 1).

Pinang merupakan salah satu tumbuhan di Indonesia yang bijinya secara tradisional digunakan sebagai obat luka bakar. Pinang mudah tumbuh di daerah tropis dan biasa ditanam di pekarangan, taman, atau di budidayakan. Pinang memiliki banyak kegunaan dari biji, daun, hingga pelepah. Biji pinang sebagai obat tradisional diantaranya sebagai obat cacingan, obat luka bakar, dan kudis. Masyarakat biasanya menggunakan biji pinang muda sebagai obat luka bakar dengan cara ditumbuk secukupnya dan di tempelkan langsung ke daerah luka bakar atau dengan cara merebus biji pinang dan air rebusannya di gunakan untuk membersihkan bagian luka dan infeksi kulit lainnya (Sudarsono et al., 1996, 2).

Biji pinang mengandung alkaloid, saponin, flavonoid, dan tanin. Saponin ini mempunyai kemampuan sebagai pembersih sehingga efektif untuk menyembuhkan luka terbuka, sedangkan tanin dapat digunakan sebagai pencegahan terhadap infeksi luka karena mempunyai daya antiseptik dan obat luka bakar. Flavonoid mempunyai aktivitas sebagai antiseptik dan alkaoloid memiliki kemapuan sebagai antibakteri (Harbone JB, 1987, 3). Tanin dalam biji pinang berkhasiat dalam meningkatkan kekuatan renggangan pada luka bakar dan penciutan pori-pori kulit (Verma DK et al., 2012, 4).
Selain biji pinang di indonesia ada juga tanaman lain yang sering digunakan untuk pengobatan luka bakar yaitu tanaman kedondong merupakan tanaman buah atau tanaman kebun yang terdapat hampir di seluruh daerah tropis. Banyak manfaat pada buah, daun dan kulit batangnya misalnya untuk pengobatan borok, kulit perih, dan luka bakar (Prihatman, 2004, 5).

Penelitian sebelumnya menunjukkan bahwa daun, kulit batang, dan kulit akar kedondong mengandung senyawa saponin, tanin, dan flavonoid. Saponin dan tanin diduga sebagai senyawa antibakteri pada daun kedondong, selain itu saponin juga memicu pertumbuhan jaringan kolagen (Inayati, 2007, 6). Senyawasenyawa flavonoid merupakan kelompok senyawa polifenol terbesar yang terdapat di alam yang bersifat sebagai antioksidan (Frengki, 2007, 7). Pemanfaatan daun kedondong sebagai obat luka bakar biasanya memerlukan campuran seperti air dan santan (Hidayat, 2012, 8).

Penelitian ini bertujuan untuk mengetahui formulasi sediaan yang terbaik dari emulgel chitosan-ekstrak biji pinang (Areca catechu .L) dan sediaan emulgel chitosan-ekstrak daun kedondong (Spondias dulcis Frost).

\section{METODE PENELITIAN}

Penelitian ini merupakan penelitian eksperimen laboratorium yang dilakukan di Laboratorium 
Farmakologi Program Studi S1 Farmasi Sekolah Tinggi Ilmu Kesehatan Borneo Cendekia Medika

\section{Alat dan bahan}

Alat yang digunakan pada penelitian kali ini adalah timbangan analitik(Mettler toledo®), ayakan mesh 200 (Lokal), alat gelas (Iwaki TE-32 Pirex ${ }^{\circledR}$ Japan), wadah gel, kandang hewan, kompor listrik (Maspion $\left.{ }^{\circledR}\right), \quad$ pencukur bulu (Gillette $\left.{ }^{\circledR}\right), \quad$ jangka sorong (Sellery $\left.{ }^{\circledR}\right)$, lempeng logam, blender (Philps ${ }^{\circledR}$ ), alat uji daya lekat, alat uji daya sebar, kertas saring, dan waterbath (Lokal).

Bahan uji yang digunakan simplisia biji pinang dan daun kedondong, Kitosan, bahan pembanding Bioplacenton salep (Kalbe Farm), bahan kimia Etanol 70\%, Tween80, Span 80, Propilenglikol, VCO, Aquades, Karbopol, NaoH, KOH, $\mathrm{HCL}, \mathrm{Mg}, \mathrm{FeCL}_{3}$. Hewan uji tikus putih betina tidak hamil, usia \pm 2 bulan, berat 180-200 gram, galur wistar.

\section{Prosedur kerja \\ Proses ekstraksi}

Serbuk simplisia yang telah dihaluskan ditimbang sebanyak $1 \mathrm{~kg}$, kemudian diekstraksi dengan cara maserasi, yaitu serbuk yang telah ditimbang dimasukkan kedalam wadah lalu ditambahkan pelarut etanol $70 \%$ sebanyak $4000 \mathrm{ml}$ dan ditutup rapat serta disimpan pada tempat yang tidak terkena sinar matahari langsung. Diamkan selama 24 jam, tetapi pada 6 jam pertama sesekali dilakukan pengadukan. Proses ekstraksi dilakukan selama 3 hari. Ekstrak disaring, dipisahkan ekstrak dan ampas. Hasil penyaringan diuapkan dengan penangas air (waterbath) hingga diperoleh ekstraksi kental biji pinang dan ditimbang untuk menghitung randemennya. Ekstrak daun kedondong (Spondias dulcis Frost) diperoleh dengan cara mengekstraksi zat aktif dari daun kedondong yang dikeringkan dan dihaluskan, kemudian dilarutkan dengan menggunakan etanol $70 \%$ direndam selama 3 hari. Hasil penyaringan lalu diuapkan dengan penangas air hingga diperoleh ekstraksi daun kedondong.

\section{Skrining Fitokimia}

Skrining fitokimia dilakukan dengan mengidentifikasi kandungan flavonoid, saponin, tanin dan alkaloid.

\section{Pembuatan Formula Emulgel Chitosan-Ekstrak Biji Pinang Dan Emulgel Kitosan-Ekstrak Daun Kedondong.}

Pembuatan gelling agent kitosan Sebanyak 2 gram serbuk kitosan dilarutkan dalam $100 \mathrm{ml}$ asam asetat $1 \%$ kemudian diaduk dan dipanaskan pada suhu $70^{\circ} \mathrm{C}$.

Pembuatan Emulgel ChitosanEkstrak Biji Pinang Dan Emulgel Kitosan-Ekstrak Daun Kedondong.

Buatlah fase air terlebih dahulu dengan menambahkan carbomer dan chitosan diaduk sampai homogen lalu dimasukan propilenglikol aduk kembali sampai homogen. Pada tempat yang berbeda dibuatlah fase 
minyak dengan menambahkan ekstrak (biji pinang dan daun kedondong), VCO dan span 80 dipanaskan aduk sampai tercampur merata. Pada wadah terpisah tween 80 juga dilakukan pemanasan. Selanjutnya fase air dan fase minyak dicampurkan dan diaduk sampai homogen kemudian ditambahkan tween 80 sedikit demi sedikit sambil dilakukan pengadukan sampai terbentuk emulgel ekstrak biji pinang. Agar mendapatkan hasil yang bagus sediaan emulgel dimixer.

Formulasi emulgel kitosan-ekstrak daun kedondong (Spondias dulcis Frost)

Tabel 1 Formulasi emulgel chitosan-ekstrak biji pinang

\begin{tabular}{|c|c|c|c|}
\hline \multirow{2}{*}{$\begin{array}{l}\text { Nama } \\
\text { Bahan }\end{array}$} & \multicolumn{3}{|c|}{ Konsentrasi (\%b/v) } \\
\hline & Placebo & F1 & F2 \\
\hline $\begin{array}{c}\text { Ekstrak } \\
\text { biji } \\
\text { pinang }\end{array}$ & - & $10 \%$ & $20 \%$ \\
\hline Chitosan & $2 \%$ & $2 \%$ & $2 \%$ \\
\hline $\begin{array}{l}\text { Propilen } \\
\text { glikol }\end{array}$ & $5 \%$ & $5 \%$ & $5 \%$ \\
\hline Carbomer & $2 \%$ & $2 \%$ & $2 \%$ \\
\hline Tween 80 & $\begin{array}{c}0,616 \\
\%\end{array}$ & $0,616 \%$ & $0,616 \%$ \\
\hline Span 80 & $\begin{array}{c}2,384 \\
\%\end{array}$ & $2,384 \%$ & $2,384 \%$ \\
\hline $\mathrm{VCO}$ & $5 \%$ & $5 \%$ & $5 \%$ \\
\hline
\end{tabular}

Tabel 2 Formulasi sediaan emulgel kitosan ekstrak daun kedondong (Spondias dulcis Frost)

\begin{tabular}{cccc} 
Bahan & \multicolumn{3}{c}{ Konsentrasi (\%b/v) } \\
\cline { 2 - 4 } & Placebo & F1 & F2 \\
\cline { 2 - 4 } $\begin{array}{c}\text { Ekstrak } \\
\text { buah }\end{array}$ & - & $10 \%$ & $20 \%$ \\
& & &
\end{tabular}

\begin{tabular}{cccc}
$\begin{array}{c}\text { mahkota } \\
\text { dewa }\end{array}$ & & & \\
Gel & $69,6 \%$ & $61,6 \%$ & $53,6 \%$ \\
Kitosan & & & \\
Propilengl & $5 \%$ & $5 \%$ & $5 \%$ \\
ikol & & & \\
Karbopol & $17,4 \%$ & $15,4 \%$ & $13,4 \%$ \\
Tween 80 & 0,616 & 0,616 & 0,616 \\
& $\%$ & $\%$ & $\%$ \\
Span 80 & 2,384 & 2,384 & 2,384 \\
& $\%$ & $\%$ & $\%$ \\
VCO & $5 \%$ & $5 \%$ & $5 \%$ \\
\hline
\end{tabular}

\section{Pengujian luka bakar}

Pada penelitian ini hewan uji dibagi menjadi 4 kelompok dan masing masing kelompok diberi perlakuan yang berbeda. Induksi luka pada punggung tikus dengan cara: tikus dicukur bulunya pada daerah punggungnya, kemudian dianastesi menggunakan etil klorida spray ditunggu 10 detik dengan durasi 30 detik lalu ditempel logam panas ke punggung tikus selama \pm 8 detik, sampai bagian dermis beserta jaringan yang terikat dibawahnya, sehingga terjadi pelepuhan dan kulit terkelupas pada bagian tertentu selanjutnya dioleskan emulgel chitosan-ekstrak biji pinang dan emulgel kitosan-ekstrak daun kedondong dilakukan 2 kali sehari. Pengukuran diameter luka dilakukan setiap hari dimulai dari hari kedua dengan menggunakan mistar. Luka dianggap sembuh bila diameter luka mencapai $0 \mathrm{~cm}$ atau telah terbentuk jaringan baru yang menutupi luka.

Analisis data. Data yang diperoleh dari penelitian ini berupa diameter luka (cm) yang diukur dengan jangka sorong. Diameter luka bakar 
yang diperoleh dihitung dengan menggunakan rumus :

$\mathrm{dx}=\frac{d \times 1+d \times 2+d x 3}{3}$

Ket :

$\mathrm{dx}$ : diameter pada hari ke $\mathrm{x}$ $\mathrm{dx}(1)(2)(3)$ : diameter luka bakar dalam berbagai arah

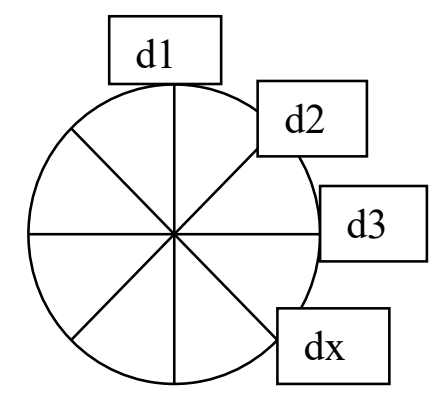

Kemudian hitung presentasi penyembuhan luka bakar dengan rumus berikut

$\mathrm{PX}=\frac{d 1^{2}-d x^{2}}{d 1^{2}} \times 100 \%$

Ket :

PX = Presentasi penyembuhan luka bakar pada hari ke $\mathrm{x}$

$\mathrm{d} 1^{2}=$ Diameter luka bakar pada hari pertama

$\mathrm{dx}^{2}=$ Diameter luka bakar pada hari $\mathrm{X}$

Data yang diperoleh dari rumus 1 dan rumus 2 di analisa dengan uji normalitas yaitu Kolmogorov Smirnov $\mathrm{Z}$ test $(\mathrm{P}<005)$. Data berdistribusi normal dilanjutkan analisis parametik (ANOVA) dan apabila data berdistribusi tidak normal dilakukan uji non parametik. Uji ANOVA untuk mengetahui perbedaan KI, KII, KIII, dan KIV terhadap penyembuhan luka bakar pada tikus.

HASIL DAN PEMBAHASAN
Pembuatan ekstrak etanol biji pinang dan daun kedondong dengan metode maserasi. Metode ini dipilih karena proses pengerjaanya yang mudah serta peralatan yang digunakan sederhana.

\section{Hasil Skrining Fitokimia}

Skrining fitokimia atau penapisan kimia adalah tahapan awal untuk mengidentifikasi kandungan kimia yang terkandung dalam tumbuhan, karena pada tahap ini kita bisa mengetahui golongan senyawa kimia yang dikandung tumbuhan yang sedang di uji/teliti.

Tabel 3. Hasil Skrining Fitokimia Ekstrak Biji Pinang

\begin{tabular}{|c|c|c|}
\hline $\begin{array}{l}\text { Identifikasi } \\
\text { senyawa } \\
\text { metabolit } \\
\text { sekunder }\end{array}$ & Pustaka & Hasil \\
\hline Alkaloid & $\begin{array}{c}\text { Endapan merah } \\
\text { jingga }\end{array}$ & + \\
\hline Flavonoid & $\begin{array}{c}\text { Lapisan kuning } \\
\text { orange atau } \\
\text { merah } \\
\text { amil alkohol }\end{array}$ & + \\
\hline Saponin & Berbusa & + \\
\hline Tanin & $\begin{array}{c}\text { Warna tua atau } \\
\text { hijau } \\
\text { kehitaman }\end{array}$ & + \\
\hline
\end{tabular}

keterangan :

(+) memberikan hasil positif

(-) memberikan hasil negatif

Tabel 4. Hasil identifikasi ekstrak daun kedondong (Spondias dulcis Fros)

\begin{tabular}{l|l|l}
\hline Kandung & Hasil & Keteran \\
\hline
\end{tabular}




\begin{tabular}{c|c|c}
\hline $\begin{array}{c}\text { an } \\
\text { senyawa }\end{array}$ & $\begin{array}{c}\text { Skrining } \\
\text { Fitokimia }\end{array}$ & gan \\
\hline $\begin{array}{c}\text { Flavonoi } \\
\text { d }\end{array}$ & $\begin{array}{c}\text { Warna } \\
\text { jingga/orange }\end{array}$ & $(+)$ \\
\hline Tanin & $\begin{array}{c}\text { Warna hijau } \\
\text { kehitaman }\end{array}$ & $(+)$ \\
\hline Saponin & $\begin{array}{c}\text { Terdapat busa } \\
\text { yang } \\
\text { bertahan } \pm 5 \\
\text { menit pada } \\
\text { lapisan atas }\end{array}$ & \\
\hline
\end{tabular}

\section{Hasil Uji Efektifitas Luka Bakar Pada Tikus Emulgel Chitosan Ekstrak Biji Pinang}

Hewan uji yang digunakan dalam penelitian ini adalah tikus putih betina dengan usia 2-3 bulan dalam keadaan sehat dengan berat 100-200 gram dan memiliki kulit normal dengan jumlah tikus sebanyak 12 ekor. Tikus dibagi menjadi 4 kelompok yaitu kontrol positif yang diberi bioplacenton, kemudian kontrol negatif diberikan placebo dan 2 kelompok uji diberikan emulgel dengan konsentrasi berbeda (10\% dan 20\%).

Pengamatan penurunan diameter luka bakar dilakukan pada hari ke- 1 , 5, 17 dan 21. Setelah perlakuan kondisi punggung tikus yang telah dilukai terlihat kecoklatan. Hal ini kemungkinan luka bakar yang dihasilkan dengan menggunakan logam panas bersifat gosong kehitaman. Metode pembuatan luka bakar dengan logam panas mempunyai beberapa kekurangan karena menghasilkan jaringan nekrosis tanpa mengalami pengelupasan kulit.
Berdasarkan hasil pengujian yang telah dilakukan maka dapat disimpulkan bahwa ternyata senyawa kimia yang terkandung dalam ekstrak biji pinang yang dapat membantu dalam proses penurunan luka bakar yang ditandai dengan mengecilnya ukuran diameter luka bakar. Hal ini didukung oleh (Handayani et al., 2016, 9) yaitu terdapat kandungan senyawa kimia berupa alkaloid, flavonoid, tanin dan saponin yang dapat menunjang kesembuhan dan memperbaiki jaringan kulit yang rusak akibat luka bakar. Emulgel chitosan ekstrak biji pinang dapat digunakan sebagai obat alternatif dalam penyembuhan luka bakar.

Mekanisme penyembuhan luka bakar emulgel chitosan ekstrak biji pinang terjadi karena didalam ekstrak biji mengandung senyawa flavonoid yang berfungsi sebagai antimikroba yang dapat mempercepat proses penyembuhan luka bakar dengan cara merusak membran sitoplasma akibatnya terjadi kematian sel mikroba. Selain itu, flavonoid memiliki efek antiinflamasi yang berfungsi sebagai anti radang dan mampu mencegah kekakuan dan nyeri yang ditimbulkan akibat luka bakar. Alkaloid berfungsi sebagai antibakteri dengan cara mengganggu komponen penyusun pada sel bakteri, sehingga lapisan dinding sel tidak terbentuk secara utuh akibatnya dapat menyebabkan kematian sel bakteri. Saponin berfungsi sebagai pembentuk kolagen yang berperan dalam proses penyembuhan luka tahap awal perbaikan jaringan yaitu dengan cara menghambat produksi 
jaringan luka yang berlebihan. Saponin sangat berperan dalam fase proliferasi. Saponin juga berfungsi sebagai antiseptik yang berfungsi membunuh kuman sehingga luka tidak mengalami infeksi yang berat.

Tanin berfungsi sebagai adstringen. Adstringen merupakan bahan pengencang yang mempunyai daya untuk mengerutkan dan menciutkan jaringan kulit, sehingga luka dapat menutup dengan cepat. Tanin juga berfungsi sebagai antioksidan yang berperan menangkap radikal bebas yang dapat menyebabkan kerusakan membran sel. Antioksidan juga diduga dapat mengurangi pelepasan mediator sel radang yang berarti dapat mempercepat fase selanjutnya untuk perbaikan jaringan-jaringan dalam proses penyembuhan luka. Tanin efektif menstimulasi pembentukkan jaringan baru dan mengangkat jaringan mati tanpa merusak sel hidup.

\section{Hasil Uji Efektifitas Luka Bakar Pada Tikus Emulgel Chitosan- Ekstrak Daun Kedondong}

Efektifitas penyembuhan luka bakar dari emulgel ekstrak daun kedondong (Spondias dulcis Frost) diuji berdasarkan luka bakar yang diinduksi logam panas dan diamati selama 21 hari. Luka bakar dibuat pada setiap tubuhnya dengan diameter luka $2 \mathrm{~cm}$. Berdasarkan Dharmawan (2015), perlukaan dibuat pada punggung bagian bawah karena apabila luka dibuat pada punggung atas tikus dikhawatirkan akan mengenai tulang punggung tikus, dan apabila dibuat pada perut tikus dikhawatirkan luka tikus akan terpengaruh dengan hal-hal lain seperti kontaminasi karena luka akan terkena sekam padi, urine, feses dan kotoran lain yang mungkin ada pada kandang tikus tersebut.

Pengamatan dilakukan melalui parameter tidak efektif, yang dimaksud tidak efektif adalah parameter tidak terjadi pengecilan diameter sama dengan 0 , kurang efektif yaitu pengecilan diameter kurang > $0 \%$ kurang $\leq$ kontrol negatif, yang dimaksud efektif adalah pengecilan diameter hasil > kontrol negatif $\leq$ kontrol positif dan sangat efektif Pengecilan diameter, hasil melebihi kontrol positif dilihat dari ada atau tidak terjadinya regenerasi sel kulit pada luka bakar dan penurunan diameter pada luka bakar selama 21 hari.

Hasil pengamatan patologi anatomi terhadap proses penyembuhan luka pada hewan coba tikus untuk kelompok perlakuan dengan placebo (kontrol negatif), kelompok perlakuan dengan bioplacenton ${ }^{\circledR}$ (kontrol positif), serta kelompok perlakuan dengan emulgel ekstrak daun kedondong (Spondias dulcis Frost) $10 \%$ dan $20 \%$.

\section{Persentase Penurunan Diameter Luka Bakar Emulgel Chitosan Ekstrak Biji Pinang}

Tabel 5. Presentase rata-rata penurunan diameter luka bakar 
Berikut ini adalah hasil penelitian yang diperoleh berupa rata-rata

\begin{tabular}{|c|c|c|c|}
\hline Perlakuan & $\begin{array}{l}\text { Hari } \\
\text { ke-1 }\end{array}$ & $\begin{array}{l}\text { Hari } \\
\text { ke-2 }\end{array}$ & PX \\
\hline (\%) & 19,12 & 1,02 & 94,58 \\
\hline $\begin{array}{l}\text { Kontrol } \\
\text { positif }\end{array}$ & $\begin{array}{c} \pm \\
1,58\end{array}$ & $\begin{array}{c} \pm \\
0,18\end{array}$ & $\begin{array}{c} \pm \\
1,15\end{array}$ \\
\hline (\%) & 17,35 & 5,62 & 67,60 \\
\hline $\begin{array}{l}\text { Kontrol } \\
\text { negatif }\end{array}$ & $\begin{array}{c} \pm \\
0,13 \\
\end{array}$ & $\begin{array}{c} \pm \\
0,11 \\
\end{array}$ & $\begin{array}{c} \pm \\
0,61 \\
\end{array}$ \\
\hline $\begin{array}{c}\text { emulgel } \\
20 \%\end{array}$ & $\begin{array}{c}16,33 \\
\pm \\
3,10\end{array}$ & $\begin{array}{c}1,11 \\
\pm \\
0,25\end{array}$ & $\begin{array}{c}92,97 \\
\pm \\
2,08\end{array}$ \\
\hline $\begin{array}{c}\text { emulgel } \\
10 \%\end{array}$ & $\begin{array}{c}16,68 \\
\pm \\
0,27\end{array}$ & $\begin{array}{c}4,31 \\
\pm \\
0,15\end{array}$ & $\begin{array}{c}74,16 \\
\pm \\
1,00\end{array}$ \\
\hline $\begin{array}{l}\text { penurunan } \\
\text { pemberian } \\
\text { (Areca }\end{array}$ & $\begin{array}{r}\text { dian } \\
\text { ekst } \\
\text { atech }\end{array}$ & L.) & $\mathrm{de}$ \\
\hline
\end{tabular}
konsetrasi $10 \%$ dan $20 \%$, pemberian bioplacenton sebagai kontrol positif dan placebo sebagai kontrol negatif. Berikut ini adalah hasil pengamatan penurunan diameter luka bakar pada tikus dapat dilihat pada tabel 5 .

Berdasarkan presentasi rata-rata hasil penurunan diameter luka bakar didapatkan hasil penurunan tertinggi yaitu pada emulgel konsentrasi $20 \%$ dan kontrol positif. Hasil persentase penyembuhan luka bakar berdasarkan grafik menunjukkan bahwa kontrol positif yang dioleskan emulgel bermerk lebih cepat menutup luka dengan persentase kesembuhan sebesar 94,58\% hal ini dikarenakan emulgel bermerk yang digunakan sebagai kontrol positif merupakan emulgel yang dipasarkan sebagai emulgel luka bakar yang sudah terkenal dan telah mengalami beberapa proses pengujian baik uji praklinik maupun uji klinik. Fungsi kontrol positif adalah sebagai pembanding apakah zat uji bisa berefek sama dengan obat luka bakar yang digunakan sebagai kontrol positif.

Kontrol negatif yang digunakan adalah placebo (basis). Kontrol negatif berfungsi untuk mengetahui apakah basis yang digunakan mempunyai efek terhadap hewan uji. Hasil persentase penyembuhan luka bakar yang dihasilkan oleh kontrol negatif sebesar $67,60 \%$. Kontrol negatif memiliki persentase penyembuhan yang tidak terlalu besar tetapi menunjukkan adanya proses penyembuhan. Hal ini karena basis dapat menghambat hilangnya kandungan air dari sel-sel kulit dengan membentuk lapisan film. Basis juga memiliki kemampuan meningkatkan hidrasi pada kulit. sifat-sifat tersebut dapat menguntungkan karena mampu mempertahankan kelembaban kulit.

Emulgel dengan konsentrasi $10 \%$ memiliki persentase penyembuhan luka sebesar 74,16\%. Emulgel dengan konsentrasi $20 \%$ mempunyai persentase penyembuhan sebesar 92,97\% hampir sama dengan kontrol positif, kemungkinan emulgel dengan konsentrasi $20 \%$ memiliki potensi dan efektitas yang sama dengan kontrol positif dalam penyembuhan luka bakar. Hal ini terbukti dengan adanya kandungan kimia pada ekstrak biji pinang yang mampu menurunkan diameter luka bakar, sehingga emulgel ekstrak biji pinang dapat digunakan sebagai alternatif pengobatan luka bakar 
derajat IIb (derajat dalam).

Untuk melihat apakah adanya efek penurunan diameter luka bakar yang signifikan dari ke- 4 kelompok perlakuan, maka dilakukan uji statistik ANOVA terhadap diameter luka bakar.

\section{Persentase Penurunan Diameter Luka Bakar Emulgel Chitosan Ekstrak Daun Kedondong}

Tabel 6 Hasil rata-rata diameter penyembuhan luka dari hari ke 1-11

\begin{tabular}{|c|c|c|c|c|}
\hline $\begin{array}{c}\text { Kelo } \\
\text { mpo } \\
\mathrm{k}\end{array}$ & $\begin{array}{c}\text { Hari } \\
1\end{array}$ & $\begin{array}{c}\text { Hari } \\
3\end{array}$ & $\begin{array}{c}\text { Hari } \\
5\end{array}$ & $\begin{array}{c}\text { Hari } \\
11\end{array}$ \\
\hline $\mathrm{K}+$ & 15,44 & 17,60 & 15,14 & 12,38 \\
& $\pm 2,3$ & $\pm 3,5$ & $\pm 1,7$ & $\pm 4,9$ \\
& 4 & 1 & 0 & 6 \\
\hline $\mathrm{K}-$ & 14,11 & 15,09 & 15,71 & 13,27 \\
& $\pm 2,1$ & $\pm 1,0$ & $\pm 1,5$ & $\pm 1,3$ \\
& 8 & 4 & 4 & 8 \\
\hline $\mathrm{F} 1$ & 14,11 & 14,73 & 16,30 & 15,23 \\
& $\pm 1,6$ & $\pm 0,1$ & $\pm 1,1$ & $\pm 3,5$ \\
& 4 & 6 & 8 & 6 \\
\hline F2 & 14,26 & 15,73 & 16,88 & 13,38 \\
& $\pm 2,0$ & $\pm 0,7$ & $\pm 2,6$ & $\pm 0,5$ \\
& 3 & 9 & 8 & 7 \\
\hline
\end{tabular}

\begin{tabular}{|c|c|c|c|c|}
\hline $\begin{array}{c}\text { Kel } \\
\text { om } \\
\text { po } \\
\mathrm{k}\end{array}$ & $\begin{array}{c}\text { Hari } \\
15\end{array}$ & $\begin{array}{c}\text { Hari } \\
19\end{array}$ & $\begin{array}{c}\text { Ha } \\
\text { ri } \\
21\end{array}$ & P21 \\
\hline K+ & 5,48 & $3,62 \pm$ & 0,6 & 95,8 \\
& $\pm 3,0$ & 1,77 & $7 \pm$ & $4 \pm 3$, \\
& 6 & & 0,5 & $61 \mathrm{~b}$ \\
& & & 9 & \\
\hline K- & 6,65 & $3,90 \pm$ & 4,3 & 67,9 \\
& $\pm 1,0$ & 1,39 & $4 \pm$ & $5 \pm 17$ \\
\hline
\end{tabular}

\begin{tabular}{|c|c|c|c|c|}
\hline & 3 & & 1,8 &, $50 \mathrm{a}$ \\
& & & 9 & \\
\hline F1 & 9,12 & $3,93 \pm$ & 1,6 & 88,5 \\
& $\pm 0,7$ & 5,60 & $8 \pm$ & $0 \pm 11$ \\
& 0 & & 1,6 &, $4 \mathrm{~b}$ \\
& & & 1 & \\
\hline F2 & 5,60 & $3,14 \pm$ & 0,5 & 96,0 \\
& $\pm 0,4$ & 2,90 & $2 \pm$ & $2 \pm 3$ \\
& 3 & & 0,4 & $66 \mathrm{~b}$ \\
& & & 6 & \\
\hline
\end{tabular}

Berdasarkan persentase rata-rata penyembuhan luka bakar selama 21 hari, kontrol negatif memiliki persentase rata-rata penyembuhan $67,95 \%$ memiliki perbedaan bermakna terhadap kontrol positif, F1 dan F2 dengan nilai signifikasinya $(p<0,05)$.

Hasil uji ANOVA terdapat efektifitas emulgel kitosan-ekstrak daun kedondong (Spondias dulcis Frost) menunjukan nilai $\mathrm{F}$ hitung $(4,523>$ 4,07). Hasil ini menunjukan adanya perbedaan efektifitas penyembuhan luka bakar antara kelompok uji $(p<$ 0,05 , sehingga $\mathrm{H} 0$ ditolak $\mathrm{H} 1$ diterima.

Hasil uji LSD kontrol positif memiliki perbedaan bermakna dibanding kontrol positif tetapi tidak memiliki perbedaan bermakna terhadap F1 dan F2. Kontrol negatif memiliki perbedaan bermakna terhadap F1 dan F2 dengan nilai signifikasinya $\quad(p>0,05) . \quad \mathrm{F} 1$ memiliki perbedaan bermakna terhadap F2 dengan nilai signifikasinya $(p>0,05) . \quad \mathrm{F} 1 \quad$ dan kontrol positif tidak ada perbedaan yang signifikan, namun F1 dan kontrol negatif ada perbedaan 
signifikan. F1 dan F2 tidak ada perbedaan signifikannya $(p<0,05)$.

Berdasarkan efektifitas emulgel ekstrak daun kedondong (Spondias dulcis Frost) dalam penyembuhan luka bakar disebabkan berbagai senyawa dalam daun kedondong, dimana daun kedondong memiliki kandungan Flavonoid, Tanin dan Saponin. Flavonoid memiliki efek antiinflamasi yang berfungsi sebagai anti radang dan mampu mencegah kekakuan dan nyeri. Saponin memiliki kemampuan sebagai pembersih dan antiseptik yang berfungsi membunuh kuman atau mencegah pertumbuhan mikroorganisme yang biasa timbul pada luka sehingga tidak mengalami infeksi. Selain itu, tanin memiliki peranan biologis yang kompleks mulai dari pengendap protein hingga penghelat logam. Tanin juga dapat berfungsi sebagai antioksidan.

Ekstrak daun kedondong konsentrasi 20\% sebesar 96,0200. Dari data diatas di dapatkan kesimpulan bahwa emulgel 20\% memiliki potensi lebih efektif dari kontrol positif terhadap penyembuhan luka bakar.

\section{KESIMPULAN}

Dari data diatas di dapatkan kesimpulan bahwa emulgel $20 \%$ memiliki potensi lebih efektif dari kontrol positif terhadap penyembuhan luka bakar.

DAFTAR PUSTAKA
Kristanto H. Perbedaan Efektifitas Perawatan Luka Bakar Derajat II Dengan Lendir Lidah Buaya (Aloe Vera) Dibandingkan Dengan Cairan Fisiologis (Normal Saline 0,9\%) Dalam Mempercepat Proses Penyembuhan [Skripsi]. Malang: Fakultas Kedokteran Universitas Brawijaya; 2005.

Sudarsono, Pudjoarinto A, Gunawan D,Wahyuonos, Donatus IA, Drajad M. Tumbuhan Obat. Yogyakarta : Pusat Penelitian Obat Tradisional Universitas Gajah Mada;1996.

Harbone JB. Metode fitokimia: penuntun cara modern menganalisis tumbuhan. Bandung : Penerbit ITB ; 1987.

Verma DK, Bharat M, Nayak D, Shanbhag T, Shanbhag V, Rajput RS. Areca catechu: Effect of topical ethanolic extract on burn wound healing in albino rats. Int $\mathrm{J}$ Pharmacol and Clin Sci. 2012;1:74-8.

Prihatman, K. 2004. Tanaman Buah Kedondong. http://ukm. pempropsu.go.id./info.detail.p hp.tanamanbuah_kedondong.

Inayati, H. 2007. Potensi Antibakteri 
Ekstrak Daun Kedondong

Bangkok (Spondias dulcis

Forst). Skripsi. Fakultas

Matematika dan Ilmu

Pengetahuan Alam Institut

Pertanian Bogor. Bogor.

Frengki. 2007. Farmasi dan Ilmu

Reseptur. Buku Ajar Farmasi.

Fakultas Kedokteran Hewan

Universitas Syiah Kuala,

Banda Aceh.

Hidayat, R. 2012. Gambaran

Mikroskopis Penyembuhan

Luka Bakar yang Diberi

Gerusan Daun Kedondong

(Spondias dulcis Forst) pada

Mencit (Mus musculus L.).

Skripsi. Fakultas Kedokteran

Hewan Universitas Syiah

Kuala. Banda Aceh. 